\title{
Review Jurnal
}

\section{Understanding The}

Canadian Foreign Policy

Ratified Comprehensive

and Progressive

Agreement for Trans-

Pacific Partnership

(CPTPP) in 2018

\section{IRMA TRI ANNISYA TOMBORA}

C1B1 17052

Ilmu Komunikasi konsentrasi Hubungan Internasional, Universitas Halu Oleo

Review

Permasalahan yang diangkat dalam penelitian ini yaitu mengenai Penandatanganan perjanjian Asia-Pacific Comprehensive and Progressive Agreement for Trans-Pacific Partnership (CPTPP), yaitu sebuah perjanjian perdagangan bebas multilateral yang sebelumnya dikenal sebagai Trans-Pacific Partnership (TPP). Dalam hal ini mengganti perjanjian TPP di mana Amerika Serikat menarik diri dari keanggotaan, CPTPP merupakan langkah signifikan menuju hubungan perdagangan dan investasi yang lebih dekat di kawasan Asia- 
Pasifik dan menetapkan standar baru yang tinggi untuk perdagangan kawasan. Dinamika pertumbuhan ekonomi kawasan Asia Pasifik membuat Kanada tertarik di kawasan ini. Dari Juni 2018 hingga Oktober 2018 enam negara meratifikasi perjanjian CPTPP, termasuk Kanada yang menjadi negara kelima yang meratifikasi perjanjian ini. Teks CPTPP menyatakan bahwa perjanjian tersebut mulai berlaku 60 hari setelah ratifikasi oleh setidaknya 50\% dari penandatangan atau enam dari sebelas negara peserta. CPTPP berlaku efektif pada tanggal 30 Desember 2018. Kebijakan Kanada dalam meratifikasi CPTPP tidak terlepas dari kepentingan nasional.

Berdasarkan dari permasalahan yang ada dalam penelitian ini bertujuan untuk menganalisis kepentingan Ekonomi Kanada dalam meratifikasi Comprehensive and Progressive Agreement for Trans-Pacific Partnership (CPTPP) pada tahun 2018. Dimana Pemerintah Kanada mengharapkan beberapa sektor ekonomi mendapatkan keuntungan dari CPTPP. Oleh karena itu, perjanjian CPTPP yang telah diratifikasi, Kanada akan memperoleh keuntungan dari liberalisasi pasar melalui penghapusan tarif. Pada Neoliberalisme ini menekankan proses penghapusan aturan pada pasar dan liberalisasi pasar internasional.

Metode yang digunakan dalam penelitian ini yaitu metode penelitian deskriptif dengan pendekatan kualitatif yang menghasilkan data deskriptif berupa kata - kata tertulis dan lisan dari narasumber serta perilaku yang diamati, dimana data yang ada dikumpulkan dari wawancara bersama narasumber dari KJRI Toronto Kanada melalui email dan dokumentasi yang dikumpulkan dari dokumen pemerintah, buku, jurnal, hasil studi akademik, dan artikel media massa.

Berdasarkan penelitian yang dilakukan, didapatkan hasil perjanjian Comprehensive and Progressive Agreement for Trans-Pacific Partnership (CPTPP) menawarkan insentif ekonomi bagi negara-negara yang menandatangani Perjanjian. Dalam Perjanjian ini, Kanada memiliki visi untuk meningkatkan pertumbuhan ekonomi negaranya. Kebijakan Kanada untuk meratifikasi perjanjian CPTPP adalah karena kepentingan ekonomi. Pertama, Kanada 
mendiversifikasi pasar ekspornya untuk mengurangi ketergantungannya yang signifikan pada pasar Amerika Serikat. Kedua, meningkatkan dan mempertahankan akses pasar di Kawasan Asia Pasifik melalui penghapusan tarif dalam Perjanjian CPTPP. Dan Ketiga dari ekspansi pasar, Kanada sekarang akan memperoleh keuntungan yang lebih besar di Asia - Pasifik karena tidak harus berbagi keuntungan dari liberalisasi perdagangan dengan Amerika Serikat.

Hasil dari penelitian ini memberikan wawasan lebih lagi bagi pembaca mengenai keuntungan dari ratifikasi perjanjian CPTPP pada tahun 2018 khususnya bagi Negara Kanada. Dari hal tersebut saran yang dapat diberikan yaitu selanjutnya dapat dilakukan penelitian lebih lanjut lagi dan memberikan wawasan yang lebih luas lagi mengenai hasil yang didapatkan Negara lain yang terlibat dalam perjanjian CTPP ini dan bukan saja Negara Kanada.

\section{References}

Faturachman Alputra, S., \& Wulandari, S. (2019). Understanding The Canadian Foreign Policy Ratified Comprehensive and Progressive Agreement for TransPacific Partnership (CPTPP) in 2018. Dynamics, 2(4), 99-110. 